\title{
Termination of the facial vein into the external jugular vein: an anatomical variation
}

\author{
Terminação da veia facial na veia jugular externa: \\ uma variação anatômica
}

\author{
Suhani Sumalatha D'Silva, Thejodhar Pulakunta, Bhagath Kumar Potu*
}

\begin{abstract}
Different patterns of variations in the venous drainage have been observed in the past. During routine dissection in our Department of Anatomy, an unusual drainage pattern of the veins of the left side of the face of a middle aged cadaver was observed. The facial vein presented a normal course from its origin up to the base of mandible, and then it crossed the base of mandible posteriorly to the facial artery. Thereafter, it joined with the anterior division of retromandibular vein to form the common facial vein, which drained into the external jugular vein directly. Sound anatomic knowledge of the above variation in facial veins is essential to the success of surgical procedures in this region.
\end{abstract}

Keywords: Vascular system, variation, facial vein.

\section{Introduction}

Deviation from the normal pattern in the vascular system is a common feature, and it is more common in the veins than in the arteries. ${ }^{1}$ The standard anatomical description of the facial veins (FV) consists of the superficial temporal vein uniting with the maxillary vein to form the retromandibular vein (RMV) within the substance of the parotid gland. The RMV then divides into its anterior and posterior divisions before emerging out at the apex of the gland. The anterior division joins with the FV slightly inferiorly and anteriorly to the angle of the mandible to form the common FV that drains into the internal jugular vein. The posterior division unites with the posterior auricular vein to form the external jugular vein.

The present article reports the case of anatomical variation in the $\mathrm{FV}$ of a cadaver undergoing dissection.

\section{Resumo}

Padrões distintos de variações na drenagem venosa já foram observados. Durante a dissecção de rotina em nosso Departamento de Anatomia, observou-se um padrão incomum de drenagem das veias do lado esquerdo da face de um cadáver de meia idade. A veia facial apresentava curso normal de sua origem até a base da mandíbula, e então atravessava a base da mandíbula posteriormente à artéria facial. A seguir, juntava-se à divisão anterior da veia retromandibular para formar a veia facial comum, que drenava diretamente para a veia jugular externa. Um bom conhecimento anatômico da variação descrita acima nas veias faciais é essencial para garantir o sucesso que procedimentos cirúrgicos nessa região.

Palavras-chave: Sistema vascular, variação, veia facial.

\section{Case report}

During routine dissection, variation in the drainage of the FV on the left side of head and neck of a middleaged male cadaver was noted. This variation was found only in one of 12 cadavers (five females and seven males) studied. The FV presented a normal course from its origin up to the base of the mandible, and then crossed the base of the mandible posteriorly to the facial artery. Thereafter, it joined with the anterior division of the RMV to form the common FV, which drained into the external jugular vein directly (Figure 1).

\section{Discussion}

The RMV has been reported to unite with the FV at a higher level in the right parotid gland..$^{2}$ A case of the right $\mathrm{FV}$ draining into the superficial temporal vein 5 mm cranially to an undivided RMV has been reported. ${ }^{3}$

* Department of Anatomy, Centre for Basic Sciences, Kasturba College, Manipal, University, Manipal, Karnataka, India.

No conflicts of interest declared concerning the publication of this case report.

Manuscript received Dec 20, 2007, accepted for publication Feb 27, 2008. 


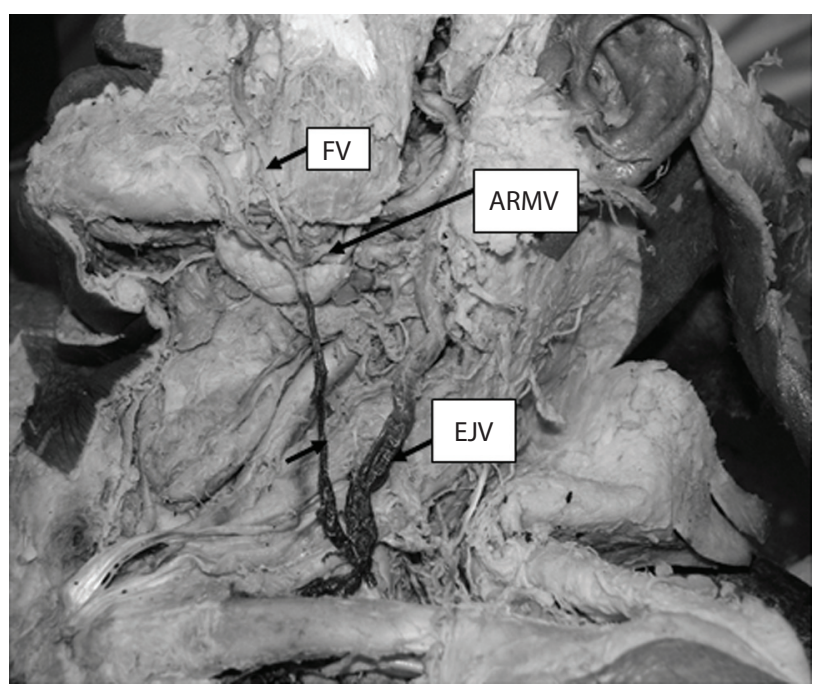

$\mathrm{ARMV}=$ anterior division of retromandibular vein; EJV = external jugular vein; FV = facial vein.

Figure 1 - Abnormal termination of facial vein into the external jugular vein

FV terminating into the external jugular vein has also been reported in the literature, ${ }^{4,5}$ as has the left common FV terminating into the left subclavian vein. ${ }^{6}$ There is a preponderance of venous variations on the right side of the face in the literature, ${ }^{7}$ contrarily to what was observed in the present case.

Knowledge of the varying venous patterns in the facial region is important for surgeons to avoid any intraoperative trial and error procedures, which might lead to excessive bleeding. In addition, these veins warrant attention for their use in surgeries involving microvascular anastomosis. ${ }^{8}$ Sound anatomic knowledge of the formation, course and tributaries of the FV is essential to the success of surgical procedures in this region.

\section{Acknowledgements}

Authors would like to thank Dr. Narga Nair for her support and cooperation. We also acknowledge Dr. K.Gopalakrishna for his help in dissecting the specimen.

\section{References}

1. Hollinshead WH. Anatomy for surgeons. 3rd ed. Jagerstown: Harper \& Row; 1982. Vol. 1. The head and neck. p. 467.

2. Kopuz C, Yavuz S, Cumhur M, Tetik S, llgi S. An unusual coursing of the facial vein. Kaibogaku Zasshi. 1995;70:20-2.

3. Peuker ET, Fischer G, Filler TJ. Facial vein terminating in the superficial temporal vein: a case report. J Anat. 2001;198(Pt 4):509-10.

4. Choudhry R, Tuli A, Choudhry S. Facial vein terminating in the external jugular vein: an embryologic interpretation. Surg Radiol Anat. 1997;19:73-7.

5. Prakash R, Prabhu LV, Kumar J, Nayak V, Singh G. Variations of jugular veins: phylogenic correlation and clinical implications. South Med J. 2006;99:1146-7.

6. Prakash BB, Bhagath KP. A rare termination of left common facial vein into left subclavian vein: a case report. Int J Morphol. 2007;25:555-6.

7. Mehra S, Kaul JM, Das S. Unusual venous drainage pattern of face: a case report. J Anat Soc India. 2003;52:64-5.

8. Nagase T, Kobayashi S, Sekiya S, Ohmori K. Anatomic evaluation of the facial artery and vein using color Doppler ultrasonography. Ann Plast Surg. 1997;39:64-7.

Correspondence:

Bhagath Kumar.Potu

Department of Anatomy

Kasturba Medical College, Manipal University

Manipal, Karnataka, India -576104

E-mail: potu_kumar2000@yahoo.co.in 